\title{
Maternal and Perinatal Outcomes in women with Hepatitis B Carrier State
}

Meei Jiun Seet ${ }^{1 *}$, Sohinee Bhattacharya ${ }^{2}$, and Ashalatha Shetty ${ }^{2}$.

${ }^{1}$ Department of Obstetrics and Gynaecology, KK Women's and Children's Hospital,UK

${ }^{2}$ Aberdeen Maternity Hospital,UK.

*Corresponding Author : Meei Jiun Seet, Department of Obstetrics and Gynaecology, KK Women's and Children's Hospital. UK.

E-mail: mailto:a.shetty@abdn.ac.uk

Received date: March 01,2019;Accepted date : March 19,2019; Published date: March 22,2019.

Citation : Meei Jiun Seet, Sohinee Bhattacharya, and Ashalatha Shetty, Maternal and Perinatal Outcomes in women with Hepatitis B Carrier State, j. Women Health Care and Issues. Doi: 10.31579/2642-9756/005

Copyright : (c) 2019 Meei Jiun Seet. This is an open-access article distributed under the terms of The Creative Commons Attribution License, which permits unrestricted use, distribution, and reproduction in any medium, provided the original author and source are credited.

\begin{abstract}
Introduction: Hepatitis B is the most common form of viral hepatitis. Much has been done for the prevention of Hepatitis B transmission from mother to child. However, there is still very limited evidence looking at maternal obstetrics and perinatal outcomes, such as gestational diabetes, antepartum haemorrhage and preterm labour, hypertensive disorders in pregnancy and small for gestational age, with Hepatitis B infected women. These adverse pregnancy outcomes, if significant, may affect future antenatal care and have a negative impact on public health. This study aims to determine the association between these adverse pregnancy and neonatal outcomes with maternal Hepatitis B carrier state.

Methods: This is a retrospective cohort study comparing adverse pregnancy and neonatal outcomes in primigravid women who delivered singleton babies after 24 completed weeks of gestation and are carrier for Hepatitis B virus with those who are non-carrier for Hepatitis B virus, between 1992 and 2013 in Aberdeen Maternity Hospital. The adverse pregnancy and neonatal outcomes studied include hypertensive disorders in pregnancy, antepartum haemorrhage, preterm birth <37 weeks, induction of labour, caesarean delivery, low birth weight and admission to neonatal unit. Data was extracted from the Aberdeen Maternity and Neonatal Databank (AMND), which was established in 1950 to record all pregnancy-related events occurring in Aberdeen city and district in the northeast of Scotland. Statistical analysis was done with SPSS version 21 using independent samples t-test for normally distributed continuous variables and chi-squared test for categorical variables. Multivariate logistic regression analysis using a multilevel random effects regression model was also conducted to adjust for confounding factors.

Results: The data set contained a sample size of 35116 primigravid women with singleton pregnancies, with 59 being carrier for Hepatitis B virus (represented by positive HBsAg status). HBsAg-positive women had significantly lower mean Body Mass Index and were more likely to be from the manual social class (registrar general's occupation-based social class). On unadjusted analysis, there were no significant differences in the prevalence of all maternal and perinatal outcomes in both groups. However, after adjusting for confounding factors, HBsAg-positive women were more likely to have smaller babies (aOR 4.28; 95\% CI 1.57-11.66).

Conclusion: Our study suggested higher frequencies of low birth weight babies in women with hepatitis B infection. We found no statistically significant differences in other adverse pregnancy and perinatal outcomes. As current evidence still shows inconsistent results, further research evaluating the possible effects of Hepatitis B viraemia on pregnancy outcomes is justified.
\end{abstract}

\section{Introduction}

Hepatitis B is the most common and serious form of viral hepatitis. According to the World Health Organization (WHO), it is estimated that more than 2 billion people worldwide have been infected with Hepatitis B virus. Of these, approximately 360 million people are at risk of developing serious problems and death, mainly due to liver cirrhosis and hepatocellular carcinoma $(\mathrm{HCC})^{(1)}$.

Much has been done for the prevention of Hepatitis B transmission from mother to child. According to the NICE clinical guideline 62, all pregnant women should be offered screening for Hepatitis B infection to identify babies who will need vaccination and immunoglobulin to prevent mother-to-child transmission of Hepatitis B infection ${ }^{(2)}$. A meta-analysis of randomised controlled trials of Hepatitis B vaccine administration at birth concluded that vaccination and Hepatitis B immunoglobulin significantly prevent Hepatitis B occurrence in newborns to Hepatitis B surface antigen (HBsAg) positive mother ${ }^{(3)}$.

However, there is still limited evidence looking at maternal and perinatal outcomes with Hepatitis B infected women. Although conflicting, in recent years, some reports have suggested that the incidence of gestational diabetes $\left.(\mathrm{GDM})^{(4-6,}, 15\right)$, antepartum haemorrhage $(\mathrm{APH})^{(4)}$ and preterm labour (PTL) ${ }^{(7-8,14)}$ are higher with Hepatitis B carrier state whilst the incidence of hypertensive disorders of pregnancy ${ }^{(5,9,16)}$ and small for gestational age $(\mathrm{SGA})^{(6,8)}$ are reduced in these women, the pathophysiology of these is not clear.
These adverse pregnancy outcomes, if significant can affect future antenatal care and have serious impact on public health.

This study aims to determine the association between these adverse pregnancy and neonatal outcomes with maternal Hepatitis B carrier state.

\section{Materials and Methods}

\section{Data source}

In 1950, The Aberdeen Maternity and Neonatal Databank (AMND) was established to record all pregnancy-related events occurring in Aberdeen city and district, in the northeast of Scotland. The medical data are coded using criteria taken from the ninth and tenth revisions of the International Classification of Diseases (ICD-9 and -10). Details of routine hepatitis B testing have been included in the AMND database only from 1992. Data for this study was extracted from this database using predetermined criteria $^{(10)}$.

\section{Study population}

The study population was limited to primigravid women in order to minimise the confounding effect of parity and to avoid double counting of infected women. We included all women who delivered singleton babies after 24 completed weeks of gestation between 1992 and 2013 in Aberdeen Maternity Hospital. 


\section{Study design}

This is a cohort study where the exposed cohort comprised of women with positive HBsAg, and the unexposed cohort comprised of women with negative $\mathrm{HBsAg}$, who delivered at the same hospital during the same time period. Demographic information including maternal age, social class, smoking status, body mass index (BMI) and antenatal and perinatal outcomes including hypertensive disorders in pregnancy (gestational hypertension, pre-eclampsia, severe pre-eclampsia and eclampsia), cholestasis, APH, PTB (coded as delivery before 37 weeks of gestation), induction of labour, low birth weight (LBW) (birth weight less than $2500 \mathrm{~g}$ ), mode of delivery and admission to neonatal unit (NNU).

\section{Statistical analysis}

Statistical analysis was done using SPSS version 21. The differences between normally distributed continuous variables were analysed using independent samples t-test and categorical variables compared using chi-squared test. Univariate analysis was conducted to identify relationships between each antenatal and perinatal outcome and HBsAg status without adjusting for confounding factors. Unadjusted odds ratio was generated. Here, binary logistic regression was used. Multivariate logistic regression analysis was carried out to identify the relationship between each maternal or perinatal outcome and HBsAg positive status by adjusting for confounding variables. Here, a multivariable random effects regression model was used. The sociodemographic variables that showed significant association at the $5 \%$ level of significance with $\mathrm{HBsAg}$ positive status on univariate analysis were included in the model to obtain adjusted odds ratios with 95\% confidence intervals.

Permission to carry out the study was granted by the steering committee of the Aberdeen Maternity and Neonatal Databank. As only anonymised routinely collected data were used in the analysis, formal ethical approval was not considered necessary by the North of Scotland Research Ethics Service.

\begin{tabular}{|c|c|c|c|c|c|c|}
\hline \multirow[t]{2}{*}{ Characteristics } & \multicolumn{2}{|l|}{ HBsAg } & \multirow{2}{*}{$\begin{array}{l}\text { Unadjusted OR } \\
\text { (95\% CI })\end{array}$} & \multirow[b]{2}{*}{ p-value } & \multirow{2}{*}{$\begin{array}{l}\text { Adjusted OR } \\
(95 \% \text { CI } *\end{array}$} & \multirow[b]{2}{*}{ p-value } \\
\hline & Positive & Negative & & & & \\
\hline Number & 59 & 35057 & - & - & - & - \\
\hline $\begin{array}{lll}\begin{array}{l}\text { Hypertensive } \\
\text { pregnancy }(\%)\end{array} & \text { disorders } & \text { in } \\
\end{array}$ & 10.2 & 20.4 & $0.44(0.19-1.03)$ & 0.05 & $0.35(0.11-1.12)$ & 0.08 \\
\hline Cholestasis $(\%)$ & 0 & 0 & - & - & - & - \\
\hline Antepartum haemorrhage (\%) & 10.2 & 13.0 & $0.76(0.33-1.77)$ & 0.70 & $0.65(0.23-1.81)$ & 0.41 \\
\hline $\begin{array}{l}\text { Mean gestation at delivery in } \\
\text { weeks (std dev) } \\
\text { Preterm birth }<37 \text { weeks }(\%)^{* *}\end{array}$ & $\begin{array}{l}39.07(3.87) \\
5.1\end{array}$ & $\begin{array}{l}39.22(2.40) \\
8.9\end{array}$ & $\begin{array}{l}0.98 \\
(0.89-1.08) \\
0.55(0.17-1.75)\end{array}$ & $\begin{array}{l}0.63 \\
0.49\end{array}$ & $\begin{array}{l}- \\
0.50(0.12-2.05)\end{array}$ & $\begin{array}{l}- \\
0.33\end{array}$ \\
\hline Induction of labour $(\%)^{* * *}$ & 35.6 & 37.5 & $0.92(0.54-1.57)$ & 0.785 & $1.39(0.75-2.56)$ & 0.30 \\
\hline $\begin{array}{l}\text { Mode of delivery } \\
\text { Vaginal delivery (including } \\
\text { instrumental) }(\%) \\
\text { Caesarean delivery }(\%) * * * *\end{array}$ & $\begin{array}{l}66.1 \\
33.9\end{array}$ & $\begin{array}{l}73.5 \\
26.5\end{array}$ & $\begin{array}{l}1.42 \\
(0.83-2.44)\end{array}$ & 0.24 & $\begin{array}{l}1.92 \\
(1.00-3.70)\end{array}$ & 0.05 \\
\hline $\begin{array}{l}\text { Mean birth weight in grams } \\
\text { (std dev) } \\
\text { Low birth weight }(\%)^{* * * * *}\end{array}$ & $\begin{array}{l}3143.22 \\
(833.36) \\
11.9\end{array}$ & $\begin{array}{l}3307.31 \\
(624.97) \\
8.4\end{array}$ & $\begin{array}{l}1.00(0.99-1.00) \\
1.47(0.67-3.25)\end{array}$ & $\begin{array}{l}0.44 \\
0.34\end{array}$ & $\begin{array}{l}- \\
4.28(1.57-11.66)\end{array}$ & $\begin{array}{l}- \\
0.005\end{array}$ \\
\hline Admission to NNU(\%)****** & 20.0 & 17.0 & $1.22(0.63-2.37)$ & 0.59 & $1.30(0.55-3.09)$ & 0.55 \\
\hline
\end{tabular}

Table 2: Association between maternal HBsAg Status and maternal and perinatal outcomes

*All adjusted OR were adjusted for maternal age, smoking, BMI and social class

**OR for preterm birth was also adjusted for induction of labour

***OR for induction of labour was also adjusted for hypertension disorder in pregnancy and antepartum haemorrhage

****OR for caesarean delivery was also adjusted for induction of labour, hypertension disorder in pregnancy and antepartum haemorrhage

$* * * * * \mathrm{OR}$ for LBW was also adjusted for induction of labour, hypertension disorder in pregnancy, antepartum haemorrhage and preterm birth

****** OR for admission to NNU was also adjusted for preterm birth and low birth weight.

\section{Results}

The data set obtained from the AMND contained a total sample size of 35 116 primigravid women with singleton pregnancies. Statistical analysis was performed on all 35116 women, with 59 being carrier for Hepatitis B virus (represented by positive HBsAg status).

Table 1 represents the sociodemographic characteristics of women in relation to their HBsAg status. HBsAg-positive women had significantly lower mean body mass index as compared to HBsAg-negative women despite similar mean maternal age and smoking status. Of women with HBsAg positive status, $66.1 \%$ were from the manual social class (registrar general's occupation-based social class), whereas $51.2 \%$ of those with HBsAg negative status were from the manual social class. This difference was statistically significant.

\begin{tabular}{|l|l|l|l|}
\hline \multirow{2}{*}{ Characteristics } & \multicolumn{2}{|l|}{ HBsAg status } & \multirow{2}{*}{ p-value } \\
\cline { 2 - 3 } & Positive & Negative & - \\
\hline Number & 59 & 35057 & 0.97 \\
\hline $\begin{array}{l}\text { Mean maternal age in } \\
\text { years (Std dev) }\end{array}$ & $27.44(4.54)$ & $27.41(5.89)$ & \\
\hline $\begin{array}{l}\text { Social class } \\
\text { Manual (\%) } \\
\text { Non-manual (\%) }\end{array}$ & 66.1 & 51.2 & $\mathbf{0 . 0 3}$ \\
\hline $\begin{array}{l}\text { Smoking status } \\
\text { Non-smoker (\%) } \\
\text { Smoker (\%) }\end{array}$ & 33.9 & 48.8 & 0.90 \\
\hline $\begin{array}{l}\text { Mean Body Mass Index } \\
\text { (std dev) }\end{array}$ & $23.09(3.12)$ & $25.01(4.92)$ & $\mathbf{0 . 0 1}$ \\
\hline $\begin{array}{l}\text { Pre-existing diabetes } \\
\text { mellitus (\%) }\end{array}$ & $0(0)$ & $274(0.8)$ & - \\
\hline $\begin{array}{l}\text { Pre-existing } \\
\text { hypertension (\%) }\end{array}$ & $1(1.7)$ & $1901(5.4)$ & 0.378 \\
\hline
\end{tabular}

Table 1: Maternal sociodemographics in relation to maternal HBsAg status.

Table 2 showed the association between maternal HBsAg status and maternal and perinatal outcomes. There were no cases of cholestasis in both groups of women. On unadjusted (univariate) analysis, there were no significant differences in the prevalence of hypertensive disorders in pregnancy, APH, PTB, IOL, caesarean delivery, LBW and admission to $\mathrm{NNU}$ in both groups. After adjusting for confounding factors, HBsAg positive women were more likely to have smaller babies compared to HBsAg negative women (adjusted OR, aOR 4.28; 95\% CI 1.57-11.66).

\section{Discussion}

Our study suggested higher frequencies of LBW babies in women with hepatitis B infection. Otherwise, we found no statistically significant differences in other adverse pregnancy and perinatal outcomes. 
The main strength of our study is that it involved a sizeable cohort of women with Hepatitis B carrier state for a very low-prevalence area. This has contributed to the existing data on maternal and perinatal outcomes of women with Hepatitis B carrier state. However, this number is still relatively very small resulting in limitations in the statistical analysis. Another weak point is that this data set included all women with positive HBsAg regardless of their stages of infection, as the AMND does not contain details of other viral antigen status or liver function tests. This would have significantly skewed the data, as treatment for acute hepatitis and fulminant liver failure might involve immediate termination of the pregnancy leading to PTB and/or caesarean delivery ${ }^{(11-13)}$. However, the likelihood of getting a case of that severity in this small number of HBsAg-positive women is low.

Studies done by Lao et al. ${ }^{(5)}$ and Connell et al. ${ }^{(6)}$ showed no association between women with Hepatitis B carrier status and babies with LBW. However, our study suggested higher frequencies of LBW babies in women with hepatitis B infection. Safir et al. ${ }^{(8)}$ reported results in accordance to our study (aOR 1.3; 95\% CI 1.1-1.7), but their data was analysed by combining women with Hepatitis B and Hepatitis C carrier status as a group. Connell et al. argued that Hepatitis B and Hepatitis $\mathrm{C}$ might not affect pregnancies in a similar way ${ }^{(6)}$.

\begin{tabular}{|c|c|c|c|c|c|}
\hline $\begin{array}{lll}\begin{array}{l}\text { Authors I } \\
\text { publication }\end{array} & \text { Year of } \\
\end{array}$ & Reddick 2010 & Tse 2005 & Lobstein 2011 & Lao 2012 & Lao 2007 \\
\hline Details of study & $\begin{array}{l}\text { USA 1995-2005 } \\
\mathrm{N}=814 \\
\text { Logistic regression Data }\end{array}$ & $\begin{array}{l}\text { Hong Kong 2000-2002 } \\
\mathrm{N}=253 \\
\text { Matched control }\end{array}$ & $\begin{array}{l}\text { Germany } \\
2001-2006 \\
\mathrm{~N}=39\end{array}$ & $\begin{array}{l}\text { Hong Kong 1995-2009 } \\
\mathrm{N}=8634 \\
\text { Retrospective cohort study }\end{array}$ & $\begin{array}{l}\text { Hong Kong1998-2001 } \\
\mathrm{N}=1138 \\
\text { (Not adjusted) }\end{array}$ \\
\hline Low social status & N/A & N/A & $\square$ (unemployed) & N/A & N/A \\
\hline Smoking & N/A & N/A & N/A & N/A & $\square$ \\
\hline Substance misuse & $\square$ & N/A & N/A & N/A & N/A \\
\hline Single marital status & N/A & N/A & NS & N/A & N/A \\
\hline BMI & N/A & NS & NS & $\square$ & $\square$ \\
\hline Hypertensive disorders & NS (PET) & NS (PET) & NS (PET) & $\square$ & $\square$ \\
\hline Gestational diabetes & NS & $\square$ & No cases & NS & $\square$ \\
\hline Cholestasis & N/A & N/A & N/A & N/A & N/A \\
\hline $\begin{array}{l}\text { Antepartum } \\
\text { haemorrhage }\end{array}$ & NS & $\square$ & NS & $\square$ & NS \\
\hline Preterm birth $<37 \mathrm{w}$ & $\square$ & NS & NS & NS & N/A \\
\hline IOL & N/A & N/A & N/A & N/A & N/A \\
\hline Caesarean delivery & $\square$ & NS & NS & N/A & NS \\
\hline Mean BW & N/A & NS & NS & $\square$ & NS \\
\hline LBW & N/A & N/A & N/A & N/A & NS \\
\hline SGA/IUGR & NS & NS & N/A & N/A & $\mathrm{NS}$ \\
\hline
\end{tabular}

Table 3: Summary of studies on effects of Hepatitis B infection in pregnancy.

\begin{tabular}{|l|l|l|l|l|}
\hline Authors / Year of publication & Safir 2010 & Wong 1999 & To 2003 & Connell 2011 \\
\hline Details of study & Israel 1988-2007 & Hong Kong June 1996- Sep 1998 & $\begin{array}{l}\text { Hong Kong 4 years } \\
\text { N=1340 }\end{array}$ & $\begin{array}{l}\text { Florida 1998-2007 } \\
\text { N=1458 }\end{array}$ \\
\hline Low social status & N/A & N=824 & Unknown & N/A \\
\hline Smoking & N/A & Unknown & Unknown & $\square$ \\
\hline Substance misuse & N/A & Unknown & Unknown & $\square$ \\
\hline Single marital status & N/A & Unknown & Unknown & N/A \\
\hline BMI & N/A & Unknown & Unknown & NS (PET) \\
\hline Hypertensive disorders & NS & Unknown & $\square$ & $\square$ \\
\hline Gestational diabetes & NS & N/A & Unknown & N/A \\
\hline Cholestasis & N/A & Unknown & Unknown & NS (abruption \& PPM) \\
\hline Antepartum haemorrhage & N/A & Unknown & Unknown & NS \\
\hline Preterm birth <37w & $\square$ & Unknown & Unknown & NS \\
\hline IOL & $\square$ & NS & Unknown & Unknown \\
\hline Caesarean delivery & $\square$ & Unknown & Unknown & N/A \\
\hline Mean BW & N/A & Unknown & Unknown & NS \\
\hline LBW & $\square$ & Unknown & Unknown & $\square$ \\
\hline SGA/IUGR & NS & NS & \\
\hline
\end{tabular}

N/A - Not available , NS - Not significant ,PET - Pre-eclampsia , PPM - Placenta Praevia.

Table 3: showed an overview of the studies looking at the effects of Hepatitis B infection in pregnancy. These studies around the world have reported conflicting results on the association of APH, PTB, IOL, caesarean delivery and admission to NNU with Hepatitis B infection status. Further research evaluating the effects of Hepatitis B viraemia on pregnancy outcomes is justified.

Auctores Publishing - Volume1-008 www.auctoresonline.org Page - 03 tudies conducted around the world still show very varied results. In our centre, we would still recommend closer monitoring of fetal growth Hepatitis B carrier women.

e found no statistically significant differences in other adverse and perinatal outcomes, which include hypertensive disorders Aregnancy, APH, PTB, IOL, caesarean delivery and admission to NNU. matched controlled study from Hong Kong ${ }^{(4)}$ and a few studies from , Germany ${ }^{(18)}$ and Israel (8) where prevalence of Hepatitis B is loction is also showed no association between hypertensive disorders of pregnancy and Hepatitis B status. On contrary, a few 作 pregnancy in women with Hepatitis B infection ${ }^{(5,9,16)}$. The most likely (n) pregnancy in women with positive HBsAg is an impaired immune response in these women which increases their immunotolerance to the embryo, thus facilitates placental implantation and contributes to a lower incidence of hypertensive disorders ${ }^{(9)}$. The number of HBsAg positive women in our study is probably too small to demonstrate significance in this matter. Hepatitis B is high found lower incidence of hypertensive disorders of 


\section{Conclusion}

Our study suggested higher frequencies of LBW babies in women with positive HBsAg status but did not find any significant differences in other adverse pregnancy and perinatal outcomes. Although current evidence still shows inconsistent results, we would recommend closer fetal growth monitoring in HBsAg positive women in our centre. A prospective research study to evaluate the effects of Hepatitis B viraemia on pregnancy outcomes is justified to provide better information to guide the antenatal care of this group of women.

\section{References}

1. World Health Organisation, Weekly Epidemiological Record. No. 40, 2 October 2009: 84, 405-420.

2. National Institute for Health and Clinical Excellence (NICE). Antenatal care for uncomplicated pregnancies. NICE clinical guideline 62. London: National Collaborating Centre for Women's and Children's Health; December 2018.

3. Lee C Hepatitis B (2006) immunisation for newborn infants of hepatitis B surface antigen-positive mothers. Cochrane Database of Systematic Reviews, (2):CD004790.

4. Tse KY, Lo LF, Lao T. (2005) The Impact of maternal HBsAg carrier status on pregnancy outcomes: A case-control study. J Hepatol. 43:371-75.

5. Lao TT, Chan BC, Leung WC, Ho LF, and Tse KY. et al, (2007) Maternal hepatitis B infection and gestational diabetes mellitus. J Hepatol. 47:46-50.

6. Connell LE, Salihu HM, Salemi JL, August EM, Weldeselasse H, et al, (2011) Maternal hepatitis B and hepatitis C carrier status and perinatal outcomes. Liver Int. 31:1163-1170.

7. Reddick KL, Jhaveri R, Gandhi M, James AH, Swamy GK. et al, (2011) Pregnancy outcomes associated with viral hepatitis. J Viral Hepat. 13:e394-e398.

8. Safir A, Levy A, Sikuler E, Sheiner E (2010) Maternal hepatitis B virus or hepatitis $\mathrm{C}$ virus carrier status as an independent risk factor for adverse perinatal outcome. Liver Int 30: 765-770.

9. Lao TT, Sahota DS, Cheng YK, Law LW, Yeung TY. et al, Maternal hepatitis B surface antigen status and incidence of preeclampsia. J Viral Hepat. 2013 May;20(5):343-9.
10. Ayorinde AA, Wilde K, Lemon JS, Campbell DM, Bhattacharya S. Data Resource Profile: The Aberdeen Maternity and Neonatal Databank (AMND) International Journal of Epidemiology 2016 vol 45(2) pp 389.

11. Mouloudi E, Vasiliadis T, Aslanidis T, Karapanagiotou A, and Papanikolaou V, et al, (2012), Preterm delivery in a parturient candidate for emergency liver transplantation after hepatitis B virus infection related fulminant liver failure. Transplant Proc. 44(9):27657.

12. Vernadakis S, Fouzas I, Kykalos S, Kaiser GM, Metzelder M, et al, Successful salvage delivery and liver transplantation for fulminant hepatic failure in a 34-week pregnant woman: a case report. Transplant Proc. 2012 Nov;44(9):2768-9.

13. Toti L, Manzia TM, Romano P, Lenci I, Baiocchi L, et al, (2010) Successful management of a same-day emergency delivery and liver transplant in a 27 weeks pregnant woman with fulminant hepatic failure. Transpl Int. 23(1):114-5.

14. Elefsiniotis I, Tsoumakas K, Vezali E, Glynouc I, Drakoulis N, et al, Spontaneous preterm birth in women with chronic hepatitis B virus infection. International Journal of Gynecology and Obstetrics 110 (2010) 241-244.

15. Lao TT, Tse KY, Chan LY, Tam KF, Ho LF.et al, (2003) HBsAg carrier status and the association between gestational diabetes with increased serum ferritin concentration in Chinese women. Diabetes Care. 26(11):3011-3016.

16. To WW, Cheung W, Mok KM. (2003) Hepatitis B surface antigen carrier status and its correlation to gestational hypertension. Aust N Z J Obstet Gynaecol. 43(2):119-22.

17. Wong S, Chan LY, Yu V, Ho L. (1999) Hepatitis B carrier and perinatal outcome in singleton pregnancy. Am J Perinatol. 16(9):485-8.

18. Lobstein S, Faber R, Tillmann HL. (2011) Prevalence of hepatitis B among pregnant women and its impact on pregnancy and newborn complications at a tertiary hospital in the eastern part of Germany.Digestion. 83:76-82. 